\title{
5. 鼻副鼻腔腪痬の治療につんて
}

\author{
吉阙博 英 - 佐 藤 靖雄 - 井上憲 文
}

（東大耳鼻科）

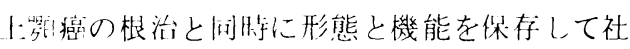
会復悄させることを標に、併用㙩法を実施して いる。今叫1968 年以降の全177例につき、1970年 までの 5 F U、B U d R 動注群、间じく、それに 減荲操作を積楎的に加えた1971年以降の群、5FU のみ動注群、挿管はしててもあえて動注を行なわな かった例も含め動注なしの群に分け、広範曲進展 例（T 4 症例）を軸に唡討して見を。

ほぼ间様な症例群を対象とした上記治療群であ

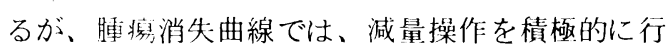
なうようになった群では、それ以前の群に比べ、 明らかに少ない照射で腫㾴が消失している。

問題となる阵発とくに再三処置例は T 4 症例に 多いが、治撩群別に見ると必ずしも動注なしの群 に多いとは言えない。

また一次治撩終了時の腫場残存、消失で比較す ると、残存群に再三処置例は多くなるが、治祢群 別に見ても差がない。

年令、性別で比較すると、必ずしも高令者に再 三処罱例は多くはなく、また女性より男性に多い 傾们がある。

組糡分類では、末分化，低分化に消失群が多い が、必ずしも腺癌等に舟三処跴例が多いとは言え ない。

既治燎例も多いか、T 3 症例では照射に化学㙩 法等保存的治憭を受けたものが多く、再三処㯰例 も多い反面、 T 1 - 症例の大部分と一部の T 4 症例では切片採取、開洞のみで紹介された例も多 く、これらは子後がよい傾问にあり、むしろ積極 的に開洞を榷めたい。

また一次治橑後の処瞋が一予後を左右する大切な 因子であるが、手術照射局所清掃と合せ行なわざ るを得なかった症例では舟三処惪例が多く、T 4 拝例でも局所清掃を繰り返し丹念に行なえた症例 は子後が洁くなる。

以上、公範曲進陸例（T 4 症例）を中心に治爒 法に考察を加えたが、T 1-3 症例に比べ、一次

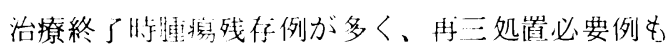

も多いが、開洞時に減量操作を積極的に行ない、 術後も出来る限り局所清掃で狪ませるようにする と、経過も良く、必ずしも、すべての症例に動注 が不可久のものでなく、広範曲進展例でも形態と 機能を保存している症例も多い。
質問 1 .
広戸（九大）

局所清掃あるいは減量操作という術語は理解出 来るが、再三処置という語は極めて文学的でその 内容を理解出来ない。その内容は部分切除術なの か照射なのか、われわれに判り易く明示して頂き たい。

質問 2 .

武井（九大）

鼻副鼻腔腫痬で制癌剂・照射の進歩で、もは や動注を必要としない症例も多くなったとは思わ れるが、動注は確かに局所濃度を高める事より、 より難治性のものには必要ではないか。

\section{質問 3 . \\ 今野（秋田大）}

動注なしと云うのは chemotherapyなしと云う 事でしょうか?

chemotherapyの内容は?

応答吉岡（東大）

答 1. 再処置、舟三処置とは、部分切除術等を主 に照射等を合せ行なうような場合を言い、外来的 に吸引，鉜除，切除等で済むような処置は局所清 掃に属すと考える。

答 2. 動注が不可欠と思われるのは、今のところ、 腺癌，悪性黒色腫等、照射効果の低いものと考え ている。

答 3. 動注なしの症例でも、もちろん局所的に 5 F U 軟膏、Bleo 固型剂等は使用している。

\section{質問 岩井（京大）}

前頭洞癌等頭蓋底に進展した症例に対する三者 併用療法はどうされていますか。 応答

\section{佐藤（東大）}

上顎三者併用療法は、野球にたとえれば 1 回戦 の裏で、まだまだ 9 回までつでいているので、一 次治㙩後も長期間経過観察し、再発を早期に発見 し粒状再発は吸引除去、それより大きいものは鉗 
除、また $5 \mathrm{~F} \mathrm{U}$ 軟高塗布や、固型剤の刺入、ある いはデンヶル手術など各例によって再治療をする。 再治療後、二度三度再発したものに、再三処置を
するわけで各操作法はそれぞれの個々の所見に応 じて完治する。 